\title{
Research Paper A study on marketing of milk by small and marginal farmers in Khammam district of Telangana state
}

\author{
Ch. Ramya Sri and K. Suhasini
}

See end of the paper for authors' affiliations Correspondence to : Ch. Ramya Sri Department of Agricultural Economics, College of Agriculture (PJTSAU), Rejendranagar (Telangana) India Email: ramya7153@gmail. com

Paper History :

Received : 14.04.2020;

Revised : 21.07.2020;

Accepted : 22.08 .2020
ABSTRACT : Dairying is recognized as an important source of income for small and marginal farmers in India, since on an average 22-26 per cent of the income of the rural households is contributed by milk. Low capital intensity, short operating cycle, steady returns make dairying a preferred livelihood activity among the small and marginal farmers. It helps to improve the status of rural masses especially weaker sections, consisting of small and marginal farmers, landless labourers and women of low income families. Cluster sampling technique is adopted for identification of three clusters which are mutually homogeneous but internally heterogeneous. The average size of family of selected marginal and small farms was 3.42 and 3.53 members, respectively. The average number of dairy animals possessed by small farmers are 1.32 units and marginal farmers are 1.47 units are small farmers and 1.47 units, respectively. Price realized for the dairy enterprise under taken is considered as key to success. In case of marginal farmers, maximum price of milk was obtained from channel through milk vendors (Rs. 44.66) followed by co-operative milk society (Rs. 42.66) and direct sale (Rs. 38). However, like marginal farmers small farmers also receive highest price from milk vendors (Rs. 46) followed by cooperatives (Rs. 42.66) and direct sale (Rs. 40). The price from milk venders is high by the farmers and the payment is prompt by them. Farmers in the study area were questioned about various government schemes and interventions for dairy farmers about which they are aware and they were beneficiaries. It was seen that none of the total respondents were taking any benefit from the government intervention. State government introduced a calf rearing programme "Sunandini" due to decreasing number of calves in the state and subsequent reduction in milk production. Telangana government has introduced a cash incentive of Rs. 4.00 per litre of milk to the state who supply milk to the state dairy federation in Telangana state.

KEY WORDS : Marketing of milk, Small, Marginal farmers

How To Cite This PAper: Ramya Sri, Ch. and Suhasini, K. (2020). A study on marketing of milk by small and marginal farmers in Khammam district of Telangana state. Internat. Res. J. Agric. Eco. \& Stat., 11 (2) : 233-236, DOI : 10.15740/HAS/IRJAES/11.2/233-236. Copyright@2020:Hind Agri-Horticultural Society. 